\title{
Retromandibular transparotid approach for subcondylar mandibular fractures: A retrospective study
}

\author{
Gökhan Göçmen, DDS, PhD, Altan Varol, DDS, PhD, Onur Atalı, DDS, PhD, \\ Sertaç Aktop, DDS, PhD, Selçuk Basa, DDS, PhD \\ Department of Oral and Maxillofacial Surgery, Marmara University Faculty of Dentistry, İstanbul-Turkey
}

\begin{abstract}
BACKGROUND: The aim was to evaluate the effectiveness and complications of retromandibular transparotid approach performed for the reduction of dislocated subcondylar fractures.

METHODS: Fourteen patients with subcondylar mandibular fractures were evaluated (8 male, 6 female, age range 19-43 years). The primary predictor variable in the present study was time (preoperative vs postoperative). The primary outcome variables were inflammatory complication, facial nerve deficit (House and Brackmann classification), and presence of parotid fistula. The secondary outcome variables were occlusal disturbances, maximal interincisal opening (MIO), and temporomandibular joint (TMJ) pain (VAS).

RESULTS: Excellent occlusion and function was observed postoperatively. One salivary fistula occurred after surgery but was healed after 3 weeks. No inflammatory complication was observed. Three patients had grade III and one patient had grade II facial nerve deficit, all recovered in 6 weeks. All patients were free of pain and no malocclusion was observed. MIO was ranging from 34 to $58 \mathrm{~mm}$ (mean $44.4 \mathrm{~mm}$ ) after 6 months.
\end{abstract}

CONCLUSION: The retromandibular transparotid approach is feasible and safe. It facilitates reduction and fixation of subcondylar fractures with functional outcomes and rare complications.

Keywords: Internal fixation; open reduction; retromandibular; subcondylar; transparotid.

\section{INTRODUCTION}

Management of subcondylar fractures is a controversial topic in maxillofacial traumatology as similar functional results have been reported with non-surgical (conservative) and open reduction and internal fixation (ORIF). ${ }^{[1]}$ However, follow-up studies have confirmed better functional outcomes with proper occlusion, temporomandibular joint function/ mobility, and faster return to preoperative status when ORIF was used. ${ }^{[2]}$

Preauricular, submandibular, face-lift, bicoronal, retromandibular, and endoscopic assisted intraoral approaches can be used alone or with combination to expose the subcondylar

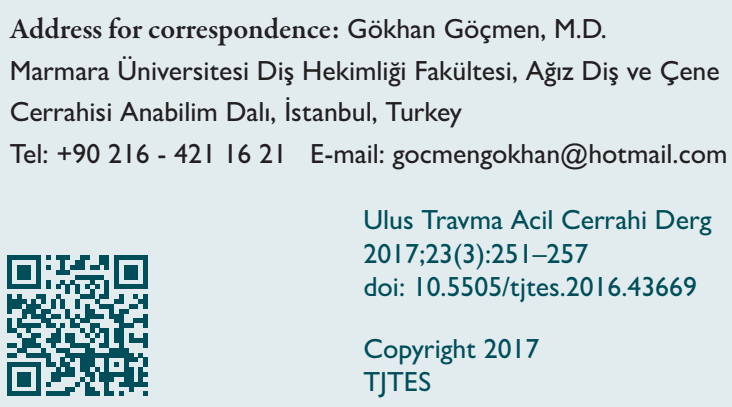

region. ${ }^{[1,3-5]}$ However, each approach has its own limits to expose directly the region of a subcondylar fracture. The only approach that allows direct access and ease of manipulation of bony stumps in such fracture pattern is the retromandibular or transparotid approach.

The aim of this study was to perform retrospective evaluation of subcondylar fractures treated between 2012-2015 years using transparotid approach.

\section{MATERIALS AND METHODS}

\section{Study Design and Sample}

This retrospective cohort study enrolled I 4 patients ( 8 male, 6 female). Ethics committee approval was obtained from the appropriate institution (Approval No: 154/6I220II). The study sample was derived from the population of patients who received ORIF for mandibular subcondylar fractures between 2012 and 2015. The mean patient age was 26 (range 19-43) years. Inclusion criteria was severely dislocated or displaced collum fractures requiring surgical reduction. Exclusion criteria were Type VI or I fractures according to Spiessl and Schroll Classification, ${ }^{[6]}$ and using additional surgical access other than the transparotid approach. 


\section{Study Variables}

The primary predictor variable in the present study was time (preoperative vs postoperative). The primary outcome variables were inflammatory complication, facial nerve deficit (I- VI House-Brackmann classification), ${ }^{[7]}$ presence of parotid fistula. The secondary outcome variables were occlusal disturbances, maximal interincisal opening (MIO), and TMJ pain (Visual Analog Scale (VAS) from no pain $=0$ to worst pain imaginable $=10$ ).

\section{Patient Selection and Treatment}

The etiology was fall, traffic accidents, interpersonal violence, and gunshot injury. Twelve patients had unilateral subcondylar fractures, two patients had bilateral subcondylar fractures and five patients had medially dislocated fracture pattern, and 5 patients had lateral overriding dislocated subcondylar fractures (Table I). Five patients had accompanying parasymphisial/ symphisial mandibular fractures.

The unilateral fracture pattern had pathognomic skeletal deformity characterized by malocclusion with significant chin deviation to fractured site and non-occlusion on contralateral site. The bilateral subcondylar fracture presented with anterior open-bite, malocclusion and absence of mandibular protrusion. Additionally, clockwise rotation of the distal segment and shortening of the posterior facial height occurred in bilateral cases.

All patients were operated using the transparotid retromandibular approach under general anesthesia. Arch bars or intermaxillary fixation (IMF) screws were placed. IMF was achieved using orthodontic elastics with $5 / 16$ size during pro- cedure and removed following rigid fixation. The parasymphisial fractures were reduced first using 2 straight adaptation miniplates (2.0 mm profile system, Trimed, Elektron Medikal, Turkey) or KLS Martin (2.0 mm CMF Trauma Module) cranio maxillofacial fracture (CMF) system.

Local hemostasis during dissection was achieved by subcutaneous injection of $2 \mathrm{ml}$ epinephrine diluted in $1000 \mathrm{cc}$ saline. Local anesthetic was avoided to facilitate facial nerve monitoring during transparotid dissection. A skin incision starting from $5 \mathrm{~mm}$ under the ear lobe was extended down to the retro-angular skin (Fig. I) until the parotid capsule was reached. The capsule was incised and blunt dissection was continued with a hemostatic clamp until the posterior border of ramus was reached. Nerve stimulator was used to identify any branches of the facial nerve running in the dissection field. None of the patients required ligation of the retromandibular vein. The Senn-Miller retractors were used to pull the skin flap from both caudal and cranial flap poles and the pterygomasseteric sling was incised sharply with no: 15 blade. The periosteum was reflected and fractures site was exposed. The ramus was retracted inferiorly to create a room for reduction of dislocated fragment with the help of a bone reduction forceps. In few cases, this traction was done using a stainless steel wire introduced with a Reverdin's needle from the submandibular region. The wire was anchored to a head of 2.0 $\mathrm{mm}$ profile titanium screw (mostly $12 \mathrm{~mm}$ in length) that was placed perpendicularly to the ramus through the retromandibular approach and caudal distraction of the distal segment was done until reduction of the fractures was completed.

Two $2.0 \mathrm{~mm}$ profile adaptation miniplates were placed at the

Table I. Description of the mandibular condylar neck fractures in 14 patients

\begin{tabular}{|c|c|c|c|c|c|c|c|}
\hline Patient & Gender & Age & $\begin{array}{c}\text { Spiessl } \\
\text { classification }\end{array}$ & Etiology & Dislocation pattern & $\begin{array}{l}\text { Accompanying } \\
\text { fractures }\end{array}$ & $\begin{array}{c}\text { Pre-op } \\
\text { MIO }\end{array}$ \\
\hline F.A. & Female & 19 & $\mathrm{Cl} 2$ & Fall & Right, lateral over-ride & No & 23 \\
\hline H.S & Male & 23 & $\mathrm{Cl} 2$ & Personal violence & Left, lateral, over-ride & No & 23 \\
\hline A.A. & Male & 38 & $\mathrm{Cl} 4$ & Fall & Right, anteromedial & No & 25 \\
\hline A.K. & Female & 19 & $\mathrm{Cl} 4$ & Fall & Left, medial & No & 22 \\
\hline S.S. & Male & 19 & $\mathrm{Cl} 2$ & Personal violence & Right, lateral over-ride & Unilateral parasymphis & 20 \\
\hline S.K. & Male & 23 & $\mathrm{Cl} 2$ & Traffic accident & Left, lateral override & No & 28 \\
\hline E.T. & Female & 43 & $\mathrm{Cl} 2$ & Personal violence & Left, lateral, over-ride & Contralateral parasymphis & 20 \\
\hline E.Ç & Male & 18 & $\mathrm{Cl} 4$ & Traffic accident & Bilateral, medial & Left parasymphis & 25 \\
\hline S.K.V & Female & 38 & $\mathrm{Cl} 4$ & Traffic accident & Right, lateral & No & 28 \\
\hline E.M.C. & Male & 23 & $\mathrm{Cl} 2$ & Traffic accident & Left, medial & No & 30 \\
\hline E.L. & Male & 15 & CL2 & Gun shot & Nondislocated & Maxillary fracture & 24 \\
\hline G.K. & Female & 34 & $\mathrm{Cl} 4$ & Fall & Bilateral medial & Symphisial & 18 \\
\hline M.K. & Female & 25 & cl 4 & Personal violence & Medial & No & 29 \\
\hline K.I. & Male & 27 & $\mathrm{Cl} 3$ & Fall & Lateral & No & 21 \\
\hline
\end{tabular}



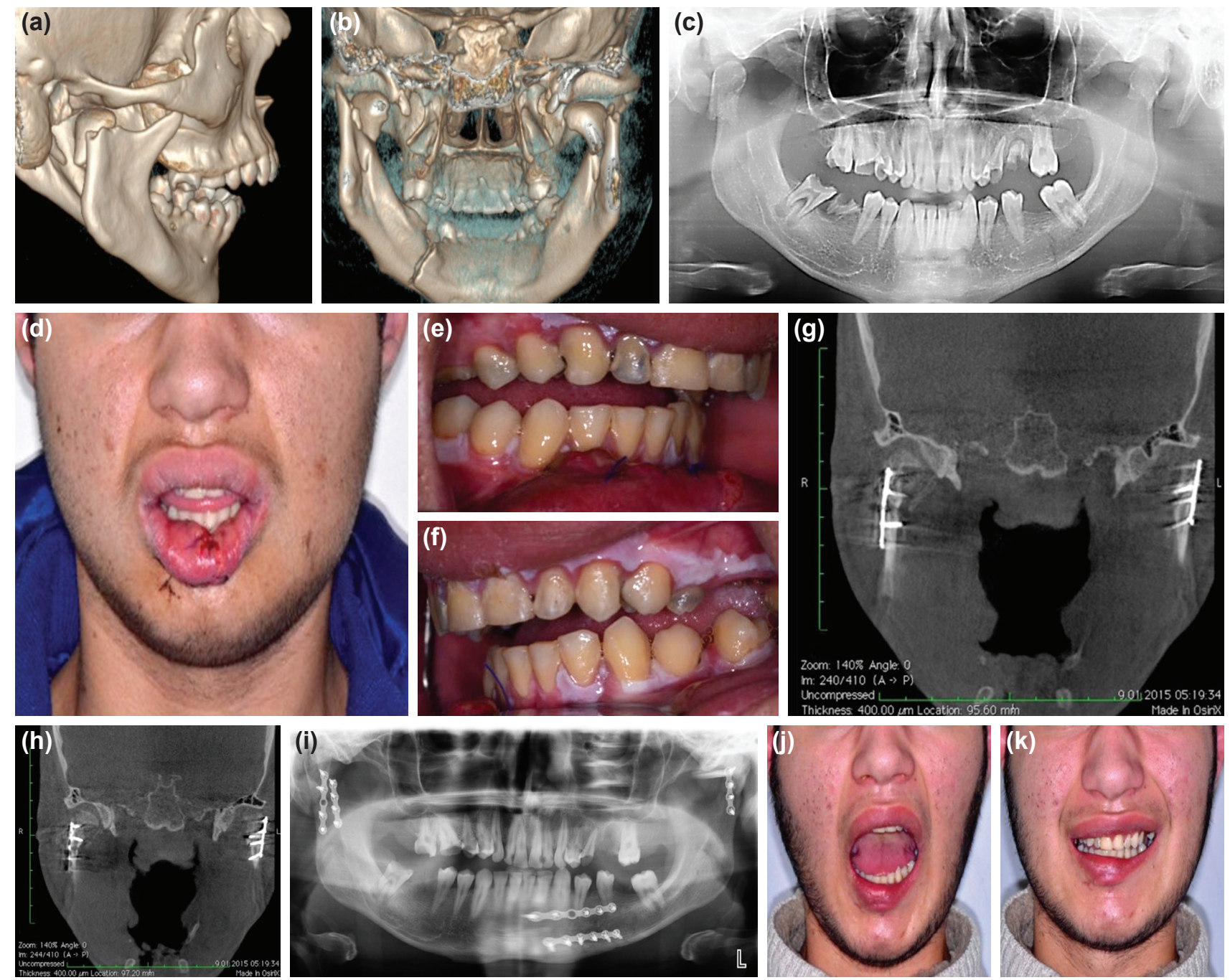

Figure 1. (a) Pre-op 3D CT view. (b) Note medially dislocated bilateral subcondylar fragment and left parasymphis fracture. (c) Shortening of the ramus height can be observed in panaromic X-Ray. (d) Extraoral view of anterior open bite. (e, f) Right and left intraoral view of open bite due to posterior premature dental contact. (g, h) Post-op coronal CT showing miniplates in position. (i) Post-op 6 months panaromic X-Ray. (j, k) Mouth opening and complete inter-occlusal relationship 1 month after surgery.

posterior and anterior region of the subcondylar fracture. The plates were placed divergent caudally to resist and overcome the pull of lateral pterygoid muscle in medially dislocated fractures owing to unfavorable fracture pattern. The anterior plate was placed parallel to mandibular notch and the posterior plate was placed parallel to border of the subcondylar region (Fig. I). In lateral over-riding fracture patterns (Fig. 2), one miniplate was placed and an additional plate was
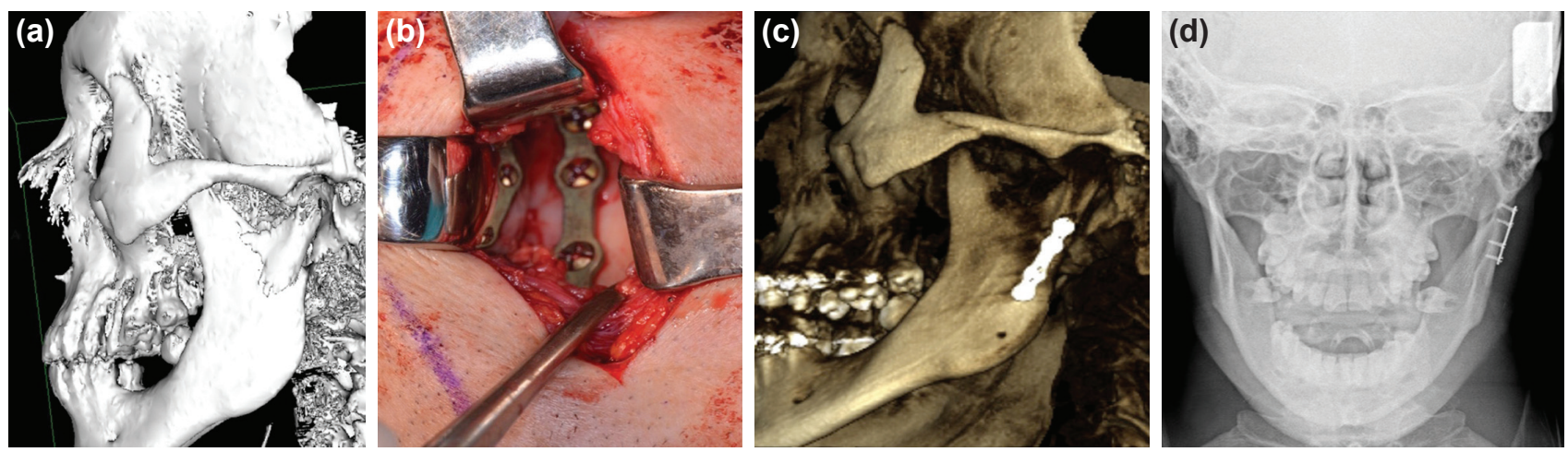

Figure 2. (a) Pre-op 3D CT view of lateral over-riding fracture of left condylar head. (b) Intra-op view of one miniplate placed parallel to border of the subcondylar region. (c) Post-op 3D CT showing miniplate in position. (d) Post-op 6 months' skull PA X-review. 

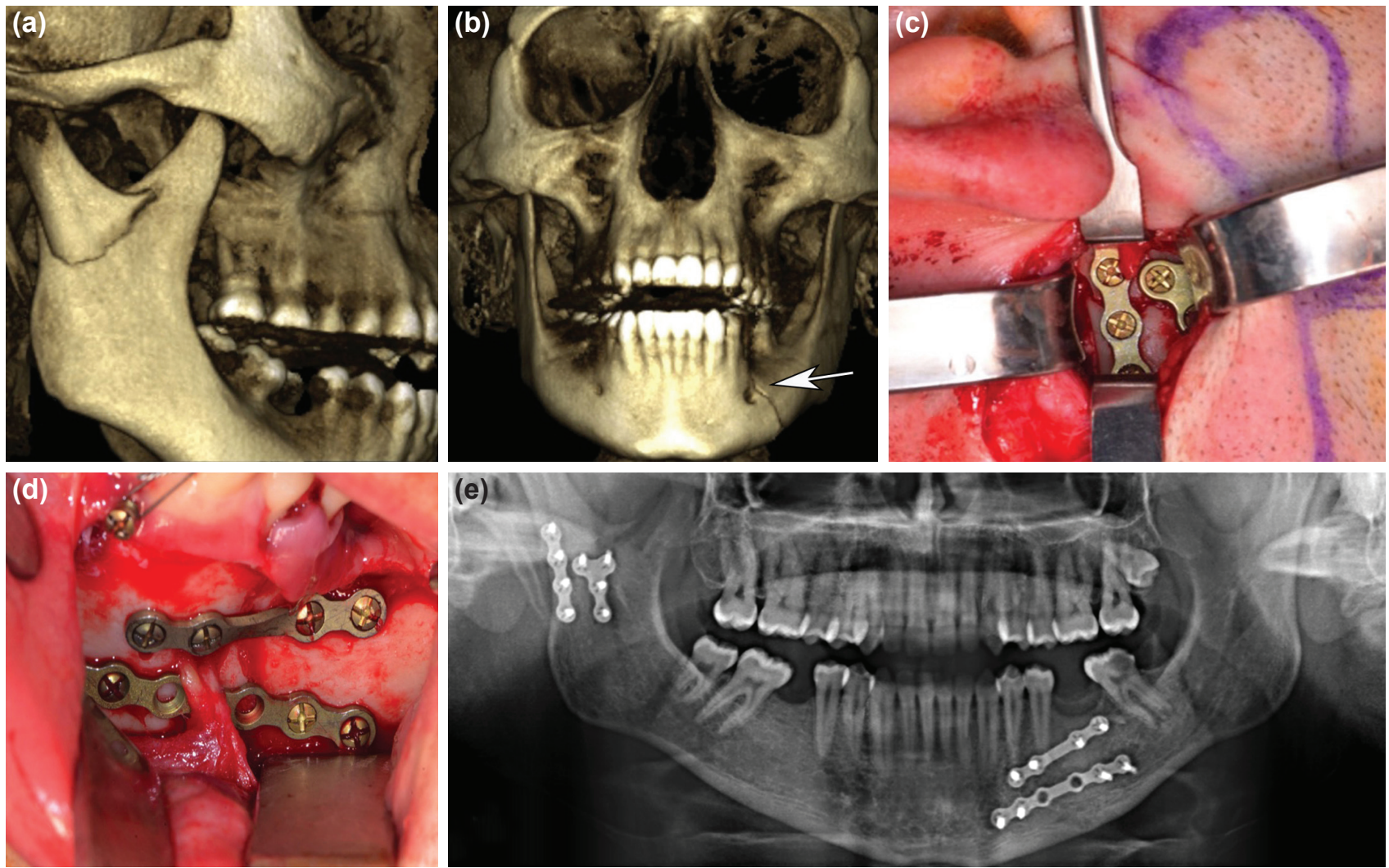

Figure 3. (a, b) Pre-op 3D CT showing right over-riding subcondylar fragment and left parasymphis fracture. (c) Intra-op view of fixation with two 2.0 miniplates, were placed at the posterior and anterior region of the subcondylar fracture. Secondary plate was used to provide minimal mobility of condylar stump. (d) 2 straight adaptation miniplates were placed for anatomic reduction of parasymphis fracture. (e) post-op 6 months panaromic X-Ray.

used to provide rigid ORIF when minimal mobility of condylar stump was observed (Fig. 3, 4). Condylar function and centric occlusion were double checked to ensure anatomic reduction after removing IMF before wound closure.

The wound was closed in layers after copious saline irrigation. We confirmed that watertight closure of the parotid capsule was achieved to avoid any salivary fistula. The skin was closed with 6-0 nylon sutures. Regime type I diet was recommended for postoperative period of 3 weeks. None of the patients were maintained under IMF following procedure. Antibiotic and non-steroidal anti-inflammatory drugs were prescribed for 5 days. The patients were encouraged to undergo physical therapy after a week.

Surgical field was checked for signs of infection (increased pain, swelling, redness, drainage of pus from the area, and fever). Occlusal disturbance was controlled observing maxillomandibular relationship in centric relation of TMJ. The pain at TMJ was evaluated using VAS and MIO for 6 months after surgery.

\section{RESULTS}

There were 8 male (57.2\%), 6 female (42.8\%) patients with age ranging between 19-43 years. The fractures were assessed as low-neck type $(n=13)(92.86 \%)$ and high neck type $(n=I)(7.14 \%)$ of the condyle/subcondylar unit. There was no patient drop out.

Six patients $(42.85 \%)$ had fracture dislocations with the condylar head out of the glenoid fossa (Spiessl \& Schroll Class IV) and 8 patients (57.I5\%) had displaced fractures (Spiessl \& Schroll Class II). Isolated fractures of the mandibular condyle were seen in 9 patients; the other 5 had additional fractures of the mandible symphisial, and I had maxillary fracture. The mechanisms of injury were fall in 5 patients, personal violence in 4 patients, traffic accidents in 4 patients, and I gunshot injury (Table I).

Salivary fistula occurred in one patient immediately after surgery which was closed spontaneously after applying pressure with dressing for 4 weeks. Three patients had Grade III facial nerve paralyzes according to House \& Brackman classification. The facial nerve paralyses resolved completely within 3 weeks in 2 patients and the other one after 6 weeks, I patient had nerve weakness in Grade II that recovered in 4 weeks.

In all patients, pre-injury occlusion and mouth opening was 

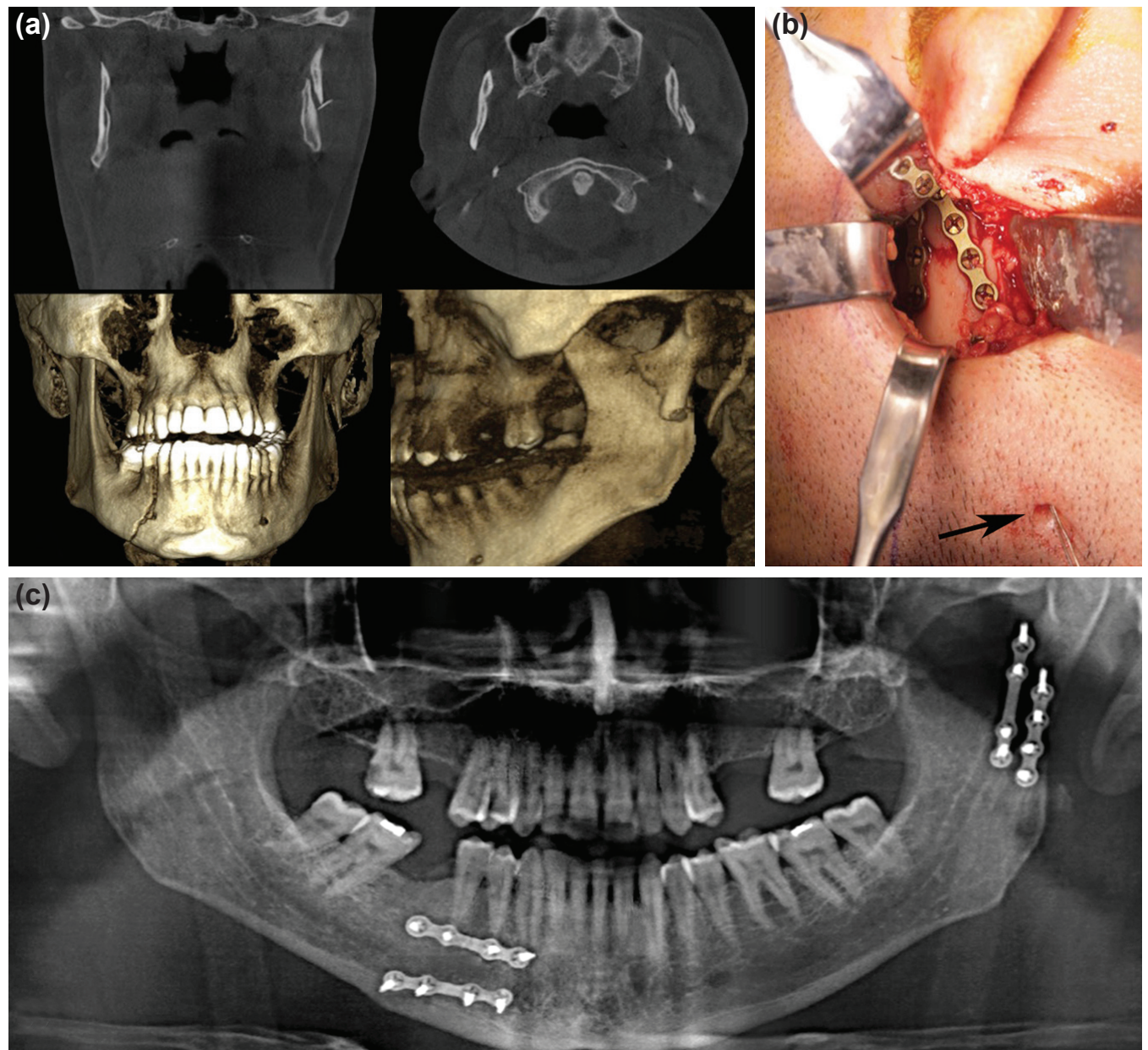

Figure 4. (a) Pre-op 3D CT view of lateral over-riding fracture of left condylar fragment and right parasymphis fracture. (b) Intra-op view of two miniplates placed after the ramus was distracted inferiorly with a stainless steel wire. (c) Post-op 6 months panaromic X-Ray.

achieved. This was assessed by clinical examination of the interdental relationship during TMJ in centric relation as well as subjectively by the patients. MIO was 34-58 mm (mean 44.4 $\mathrm{mm}$ ). All operated 16 joints were pain free after 6 months. There were 4 cases $(29 \%)$ with facial nerve injury, affecting the buccal or marginal mandibular branches or both (Grade II or III / House \& Brackmann classification). Facial nerve injuries in those cases resolved spontaneously and completely after 3-6 weeks. No plate fractures were observed in our cases serial. Postoperative salivary fistulae developed in I patient (7\%), and lasted for 4 weeks. No incident of greater auricular nerve anesthesia/ paresthesia, postoperative hematoma and wound infection was observed (Table 2).

\section{DISCUSSION}

The treatment approach to the mandibular condyle fractures is one of the most widely debated subject in maxillofacial traumatology ${ }^{[8]}$ Conservative treatment may lead to malocclusion, anterior open-bite, facial asymmetry, internal derangement, chronic joint pain, and reduced mobility. ${ }^{[9]}$ The miniplate osteosynthesis of the subcondylar process using an extraoral approach is currently the most popular method followed by the miniplate osteosynthesis using a transoral approach. ${ }^{[10]}$ The purpose of this study was to conduct retrospective evaluation of subcondylar fractures treated using retromandibular transparotid approach.

Although ORIF provides better function and anatomical reduction, possible risk of injuring to the facial nerve is the major complication that discourages many surgeons to perform ORIF with any transcutaneous open approach. ${ }^{[3]}$ The traditional retromandibular approach may lead to facial nerve injury in $30 \%$ cases. $^{[1,12]}$ Preauricular and submandibular approaches are other options that might be used for open reduction, as they facilitate better exposure of the operating field from caudal and cranial side, and simplify fracture repositioning compared to the cosmetically more favorable transoral approach or its endoscopically assisted modifications. ${ }^{[2,4]}$

However, a more forceful retraction of the soft tissues might be necessary because of the longer working distance, implying a higher risk of facial nerve disturbances. ${ }^{[13]}$ Additionally, temporal, and zygomatic branches of the facial nerve might be 
Table 2. Postoperative assessment of outcome variables

\begin{tabular}{|c|c|c|c|c|c|c|}
\hline Patient & $\begin{array}{l}\text { House-Brackman } \\
\text { Grading System }\end{array}$ & $\begin{array}{l}\text { Parotid } \\
\text { fistula }\end{array}$ & $\begin{array}{l}\text { Surgical site } \\
\text { infection }\end{array}$ & Malocclusion & $\begin{array}{c}\text { Maximal interincisal } \\
\text { opening }\end{array}$ & $\begin{array}{c}\text { Temporomandibular } \\
\text { joint pain }\end{array}$ \\
\hline F.A. & I & No & No & No & 44 & 0 \\
\hline H.S & 1 & No & No & No & 48 & 0 \\
\hline A.A. & 1 & No & No & No & 50 & I \\
\hline A.K. & I & No & No & No & 34 & I \\
\hline S.S. & 1 & Yes & No & No & 47 & 0 \\
\hline S.K. & I & No & No & No & 41 & 0 \\
\hline E.T. & I & No & No & No & 38 & I \\
\hline E.Ç & III & No & No & No & 44 & 0 \\
\hline S.K.V & III & No & No & No & 40 & 0 \\
\hline E.M.C. & I & No & No & No & 58 & I \\
\hline E.L. & II & No & No & No & 42 & 0 \\
\hline G.K. & 1 & No & No & No & 46 & I \\
\hline M.K. & III & No & No & No & 52 & 0 \\
\hline K.I. & I & No & No & No & 38 & 0 \\
\hline
\end{tabular}

vulnerable with rhytidectomy and preauricular approaches. ${ }^{[14]}$ In our study, the occurrence of nerve involvement was low, which might be related to the use of nerve stimulator, short distance of soft tissue dissection, and careful blunt transparotid dissection.

Localization and fracture pattern, age, visualization and the ability to reduce fracture stumps, and postoperative complications (occlusal disturbances, fixation failures, infection, or parotid fistula etc.) are mostly discussed topics to determine the most appropriate approach to the condylar fracture. The position of a preauricular approach is too high for subcondylar fractures. Extra difficulty may be encountered in case of low-level subcondylar fracture with this approach, which may necessitate the use of a transbuccal trocar to insert caudal screws. ${ }^{[15]}$

The submandibular approach is mostly preferred for mandibular body and mandibular angle fractures. ${ }^{[16]}$ Intraoral approach prevents cutaneous scars and there is relatively no risk of injuring the facial nerve; but the intraoral endoscopic approach is generally preferred for lateral overriding fractures since reduction of medially dislocated subcondylar fractures is hardly accomplished with the endoscopic technique. ${ }^{[5]}$

Compared with the above-mentioned approaches, the retromandibular approach is advantageous since it provides the shortest distance from the skin to the fracture and allows wide access to the posterior border of the mandible and sigmoid notch. Furthermore, it provides easier manipulation of muscle traction forces, reduction of medially dislocated fracture segments, and correct placement both of the mini- plates. $^{[2,17]}$ Therefore, this approach might facilitate successful and more stable miniplate osteosynthesis and thereby clinical and functional outcomes of the surgery. For this reason, we evaluated $\mathrm{MIO}$ and occlusal disturbances by the means of functional rehabilitation of the temporomandibular joint as the secondary outcomes variables.

This approach was first described by Hinds and Girotti and modified by Koberg and Momma. ${ }^{[18,19]}$ Modifications like transparotid, ${ }^{[1]}$ transmasseteric anteroparotid, ${ }^{[20]}$ and high cervical transmasseteric anteroparotid ${ }^{[21]}$ were also described. Earlier low popularity of the transparotid approach may be related to the possible injury of facial nerve occurring mostly during paranchymal parotid dissection and anticipated establishment of salivary fistula. ${ }^{[22]}$ Ellis $^{\left[{ }^{[1]}\right]}$ and Vesnaver ${ }^{[23]}$ reported parotid salivary fistula in $2.3 \%$ and $14 \%$ of cases, respectively, which was not reported by Bindra. ${ }^{[24]}$ In our study, although we performed a watertight closure of the parotid gland capsule, one patient developed a salivary fistula after removal of drain. The possible reason for this could be the problem with the suturing of the parotid capsule. Therefore, the meticulous and exact closure of the capsule may be considered as the most important measure in the prevention of salivary fistulas. ${ }^{[13]}$

In conclusion, transparotid approach presents shortest and direct access for reduction of subcondylar mandibular fractures. The incidence of facial nerve injuries with this approach is relatively low which should not prevent surgeons to perform anatomical reduction with transparotid retromandibular access.

Conflict of interest: None declared. 


\section{REFERENCES}

1. Handschel J, Rüggeberg T, Depprich R, Schwarz F, Meyer U, Kübler NR, et al. Comparison of various approaches for the treatment of fractures of the mandibular condylar process. J Craniomaxillofac Surg 2012;40:397401. [CrossRef]

2. Ellis E 3rd, Dean J. Rigid fixation of mandibular condyle fractures. Oral Surg Oral Med Oral Pathol 1993;76:6-15. [CrossRef]

3. Kyzas PA, Saeed A, Tabbenor O. The treatment of mandibular condyle fractures: a meta-analysis. J Craniomaxillofac Surg 2012;40:438-52.

4. Lachner J, Clanton JT, Waite PD. Open reduction and internal rigid fixation of subcondylar fractures via an intraoral approach. Oral Surg Oral Med Oral Pathol 1991;71:257-61. [CrossRef]

5. Martin M, Lee C. Endoscopic mandibular condyle fracture repair. Atlas Oral Maxillofac Surg Clin North Am 2003;11:169-78. [CrossRef]

6. Spiessl B, Schroll K. Spezielle Frakturenund Luxationslehre. Ein kurzes Handbuch in fünf Bänden. Band I/1 Gesichtsschädel 1972:317.

7. House JW, Brackmann DE. Facial nerve grading system. Otolaryngol Head Neck Surg 1985;93:146-7. [CrossRef]

8. Saponaro A, Stecco A, Brucoli M, Armienti F, Stellin L, Favano F, et al. Magnetic resonance imaging in the postsurgical evaluation of patients with mandibular condyle fractures treated using the transparotid approach: our experience. J Oral Maxillofac Surg 2009;67:1815-20. [CrossRef]

9. Brandt MT, Haug RH. Open versus closed reduction of adult mandibular condyle fractures: a review of the literature regarding the evolution of current thoughts on management. J Oral Maxillofac Surg 2003;61:1324-32.

10. Klatt J, Pohlenz P, Blessmann M, Blake F, Eichhorn W, Schmelzle R, et al. Clinical follow-up examination of surgically treated fractures of the condylar process using the transparotid approach. J Oral Maxillofac Surg 2010;68:611-7. [CrossRef]

11. Ellis E 3rd, McFadden D, Simon P, Throckmorton G. Surgical complications with open treatment of mandibular condylar process fractures. J Oral Maxillofac Surg 2000;58:950-8. [CrossRef]

12. Tang W, Gao C, Long J, Lin Y, Wang H, Liu L, et al. Application of modified retromandibular approach indirectly from the anterior edge of the parotid gland in the surgical treatment of condylar fracture. J Oral Maxillofac Surg 2009;67:552-8. [CrossRef]

13. Dalla Torre D, Burtscher D, Widmann G, Pichler A, Rasse M, Puelacher
W. Surgical treatment of mandibular condyle fractures using the retromandibular anterior transparotid approach and a triangular-positioned double miniplate osteosynthesis technique: A clinical and radiological evaluation of 124 fractures. J Craniomaxillofac Surg 2015;43:944-9.

14. Yang L, Patil PM. The retromandibular transparotid approach to mandibular subcondylar fractures. Int J Oral Maxillofac Surg 2012;41:494-9.

15. MacArthur CJ, Donald PJ, Knowles J, Moore HC. Open reduction-fixation of mandibular subcondylar fractures. A review. Arch Otolaryngol Head Neck Surg 1993;119:403-6. [CrossRef]

16. Widmark G, Bågenholm T, Kahnberg KE, Lindahl L. Open reduction of subcondylar fractures. A study of functional rehabilitation. Int J Oral Maxillofac Surg 1996;25:107-11. [CrossRef]

17. Kanno T, Sukegawa S, Tatsumi H, Nariai Y, Ishibashi H, Furuki Y, et al. The retromandibular transparotid approach for reduction and rigid internal fixation using two locking miniplates in mandibular condylar neck fractures. Int J Oral Maxillofac Surg 2014;43:177-84. [CrossRef]

18. Hinds EC, Girotti WJ. Vertical subcondylar osteotomy: a reappraisal. Oral Surg Oral Med Oral Pathol 1967;24:164-70. [CrossRef]

19. Koberg WR, Momma WG. Treatment of fractures of the articular process by functional stable osteosynthesis using miniaturized dynamic compression plates. Int J Oral Surg 1978;7:256-62. [CrossRef]

20. Wilson AW, Ethunandan M, Brennan PA. Transmasseteric antero-parotid approach for open reduction and internal fixation of condylar fractures. Br J Oral Maxillofac Surg 2005;43:57-60. [CrossRef]

21. Trost O, Abu El-Naaj I, Trouilloud P, Danino A, Malka G. High cervical transmasseteric anteroparotid approach for open reduction and internal fixation of condylar fracture. J Oral Maxillofac Surg 2008;66:201-4.

22. Chossegros C, Cheynet F, Blanc JL, Bourezak Z. Short retromandibular approach of subcondylar fractures: clinical and radiologic longterm evaluation. Oral Surg Oral Med Oral Pathol Oral Radiol Endod 1996;82:248-52. [CrossRef]

23. Vesnaver A, Gorjanc M, Eberlinc A, Dovsak DA, Kansky AA. The periauricular transparotid approach for open reduction and internal fixation of condylar fractures. J Craniomaxillofac Surg 2005;33:169-79. [CrossRef]

24. Bindra S, Choudhary K, Sharma P, Sheorain A, Sharma CB. Management of mandibular sub condylar and condylar fractures using retromandibular approach and assessment of associated surgical complications. J Maxillofac Oral Surg 2010;9:355-62. [CrossRef]

\section{ORİJINAL ÇALIŞMA - ÖZET}

\section{Subkondiler mandibula kırıklarına retromandibular transparotid yaklaşım: Geriye dönük bir çalışma}

\section{Dr. Gökhan Göçmen, Dr. Altan Varol, Dr. Onur Atalı, Dr. Sertaç Aktop, Dr. Selçuk Basa}

Marmara Üniversitesi Diş Hekimliği Fakültesi, Ağız Diş ve Çene Cerrahisi Anabilim Dalı, İstanbul

AMAÇ: Bu çalışmanın amacı dislokasyon olmuş subkondiler kırıkların redüksiyonunda uygulanan retromandibular transparotid yaklaşımın etkinliğinin ve komplikasyonlarının değerlendirilmesidir.

GEREÇ VE YÖNTEM: Subkondiler mandibular kırık görülen 14 hasta değerlendirildi (8 erkek, 6 kadın, yaş aralığı: 2I-56). Bu çalısmada ameliyat öncesi ve sonrasında elde edilen sonuçlar karşılaştıııldı. Birincil olarak değerlendirilen sonuçlar iltihabi komplikasyon gelişimi, fasiyal sinir hasarı (House ve Brackmann sınıflandırmasına göre) ve parotis fistül oluşumu idi. İkincil olarak değerlendirilen sonuçlar oklüzyon bozuklukları, maksimum ağız açıılığı ve temporomandibular eklemde görülen ağrıydı. (Görsel Analog Skalası'na göre).

BULGULAR: Ameliyat sonrası dönemde hatasız bir oklüzyon ve fonksiyon gözlemlendi. Bir hastada parotis fistül oluştu fakat üç hafta içerisinde kapandı. Hiçbir hastada iltihabi komplikasyon gelişmedi. Üç hastada 3. seviye, bir hastada 2. seviye fasiyal sinir hasarı gelişti, fakat bütün fasiyal sinir hasarlarının altı hafta içerisinde iyileşti. Hiçbir hasta da ağıı veya oklüzyon bozukluğu olmadı. Alıı ay sonraki maksimum ağız açıklığı 34-58 mm (ortalama $44.4 \mathrm{~mm}$ ) olarak ölçüldü.

TARTIŞMA: Retromandibular transparotid yaklaşım kullanışlı ve güvenli bir yaklaşıındır. Subkondiler kırıkların redüksiyonunu ve fiksasyonunu kolaylaşlaştıran bu yaklaşımda komplikasyon oranı az olup fonksiyonel sonuçlar elde edilir.

Anahtar sözcükler: Açık redüksiyon; internal fiksasyon; retromandibular; subkondiler; transparotid.

Ulus Travma Acil Cerrahi Derg 2017;23(3):25I-257 doi: 10.5505/tjtes.2016.43669 